\title{
Evaluation of the antimicrobial activity and safety of Rhus vulgaris (Anacardiaceae) extracts
}

Angela Mutuku1*, Lizzy Mwamburi', Lucia Keter², Joyce Ondicho², Richard Korir ${ }^{3}$, James Kuria², Timothy Chemweno ${ }^{1}$ and Peter Mwitari ${ }^{2}$

\begin{abstract}
Background: Medicinal plants have been used in the treatment of various ailments in most developing countries. Oral infections are the most prevalent diseases in man. The Rhus family has been found to have antimicrobial, antimalarial, and anti-inflammatory properties. Few studies have been done on Rhus vulgaris Meikle. A study was conducted to determine the effect of Rhus vulgaris Meikle stem bark extracts against selected oral pathogenic microorganisms and the safety of the extracts in vitro and in vivo.
\end{abstract}

Methods: Methanol:dichloromethane (1:1), methanol and aqueous extracts were tested for bacteriostatic and bactericidal effects against Methicillin Resistant Staphylococcus aureus (MRSA), Staphylococcus aureus, Streptococcus mutans and Candida albicans. Cytotoxicity of the active extracts was determined using Vero E6 cell lines while safety was evaluated in mice and rats. Phytochemical screening was performed on the methanol extracts. One-way ANOVA and Tukey's multiple comparisons tests were performed using IBM SPSS statistics 20.0 for antimicrobial assay and acute toxicity testing. Oneway ANOVA and Dunnett's multiple comparison tests were conducted using GraphPad Prism 8.0 for cytotoxicity assay.

Results: Methanol extract of Rhus vulgaris showed significant antimicrobial activity against MRSA (12.00 $\pm 0.00 \mathrm{~mm}$; $p$ value of < 0.005; Minimum Inhibitory Concentration of $0.391 \mathrm{mg} / \mathrm{ml}$; Minimum Bactericidal Concentration of $1.563 \mathrm{mg} / \mathrm{ml})$. The extract were not cytotoxic at $100 \mu \mathrm{g} / \mathrm{ml}$ which was the highest tested concentration. In acute dermal irritation testing, the methanol extract resulted in mild irritation with erythema and flaking that cleared within 8 days. There were no observable adverse effects from oral administration of the extracts (acute oral toxicity testing) at concentrations of 50 $\mathrm{mg} / \mathrm{kg}, 300 \mathrm{mg} / \mathrm{kg}$ and $2000 \mathrm{mg} / \mathrm{kg}$. Tannins, saponins, flavonoids, terpenoids, glycosides, alkaloids and phenols were detected in the methanol extract.

Conclusions: Antimicrobial activity of R. vulgaris extracts supports its traditional use as a toothbrush. Cytotoxicity demonstrated by the extracts as well as the mild skin irritation warrants further study before $R$. vulgaris can be recommended for the development of effective and safe mouthwashes.

Keywords: Rhus vulgaris, Antimicrobial, Antifungal, Cytotoxicity, Safety, Acute toxicity, Plant extracts

\footnotetext{
* Correspondence: angela_mutuku@yahoo.com

${ }^{1}$ Department of Biological Sciences, University of Eldoret, P.O. Box 1125-30100, Eldoret, Kenya

Full list of author information is available at the end of the article
}

(C) The Author(s). 2020 Open Access This article is licensed under a Creative Commons Attribution 4.0 International License, which permits use, sharing, adaptation, distribution and reproduction in any medium or format, as long as you give appropriate credit to the original author(s) and the source, provide a link to the Creative Commons licence, and indicate if changes were made. The images or other third party material in this article are included in the article's Creative Commons licence, unless indicated otherwise in a credit line to the material. If material is not included in the article's Creative Commons licence and your intended use is not permitted by statutory regulation or exceeds the permitted use, you will need to obtain permission directly from the copyright holder. To view a copy of this licence, visit http://creativecommons.org/licenses/by/4.0/. The Creative Commons Public Domain Dedication waiver (http://creativecommons.org/publicdomain/zero/1.0/) applies to the data made available in this article, unless otherwise stated in a credit line to the data. 


\section{Background}

Globally, oral diseases are highly prevalent and pose a major public health challenge [1]. Oral microbiota, that cause oral diseases, have developed resistance against some antibacterial agents such as metronidazole, tetracycline, erythromycin, cephalosporin and penicillin [2]. Some antimicrobials also have unfavorable side effects such as toxicity, teeth staining, diarrhea, vomiting and the alteration of the oral cavity normal flora [2]. Chlorhexidine mouth wash for example has been shown to result in teeth staining, oral mucous membrane staining, increased calculus formation, parotid swelling, desquamation of the oral mucosa and urticaria [3]. Other antibacterial agents that also result in unfavorable side effects such as toxicity are amine fluorides, cetylpyridinium and chloride [2]. The development of antimicrobial resistance and side effects caused by the current antimicrobials has resulted in a need for alternatives that are safe, userfriendly and cost-effective [2]. Extracts from some plants have been found to be efficacious against oral diseases. Aloe barbadensis, Ocimum sanctum, Acacia nilotica, Eucalyptus camaldulensis, Hibiscus sabdariffa, Psidium guajava, Mangifera indica, Rosa indica, and Azadirachta indica Miller have demonstrated inhibitory properties against some dental caries and periodontal pathogens [4]. Their activity is postulated to be through the inhibition of microbial growth and bacterial adhesion in biofilms formed on the tooth surface [5].

Rhus vulgaris Meikle (Anacardiaceae) is found in tropical and temperate regions [6]. In Kenya, the stem bark of this plant is used in the treatment of malaria [7]. In Uganda, this plant is used for the treatment of toothaches [8] and it is one of the most commonly used chewing sticks [9]. In Tanzania, $R$. vulgaris leaves are traditionally used for the treatment of dental problems and as a refreshment in herbal teas [10]. In regions surrounding Lake Victoria in East Africa, $R$. vulgaris fruits are used for the treatment of tooth ache, coughing, syphilis, gastrointestinal disorders and for the prevention of infections [11]. The Rhus genus has demonstrated significant antimicrobial, antifungal, antiviral, antioxidant, antimalarial and cytotoxic properties [6]. The aqueous extracts of $R$. vulgaris have been reported to possess good antibacterial activity against Streptococcus mutans [9]. The dichloromethane, ethyl acetate and aqueous extracts of $R$. vulgaris stem bark, root and leaf have shown antibacterial activity against Proteus mirabilis, Klebsiella oxytoca, Klebsiella pneumoniae, Salmonella typhi, Escherichia coli, Pseudomonas aeruginosa and Salmonella kisarawe with MIC values ranging from $0.39 \mathrm{mg} / \mathrm{ml}$ to $25 \mathrm{mg} / \mathrm{ml}$ while gentamycin, positive control, exhibited MIC values ranging from $0.003 \mathrm{mg} / \mathrm{ml}$ to $0.25 \mathrm{mg} / \mathrm{ml}$ [10]. The dichloromethane, ethyl acetate and aqueous extracts of $R$. vulgaris stem bark, root and leaf have also demonstrated antifungal activity against Candida albicans and Cryptococcus neoformans with MIC values ranging from $1.56 \mathrm{mg} / \mathrm{ml}$ to $25 \mathrm{mg} / \mathrm{ml}$ while fluconazole, positive control, demonstrated an MIC value of $0.19 \mathrm{mg} / \mathrm{ml}$ [12]. The aqueous extracts of $R$. vulgaris $(500 \mathrm{mg} / \mathrm{ml})$ stem bark, root and leaf have demonstrated good antioxidant activity of $80.11,80.25$ and $80.62 \%$ respectively at $30 \mathrm{~min}$ [11]. $R$. vulgaris methanolic extract (1000 $\mathrm{mg} / \mathrm{kg}$ ) showed greater anti-inflammatory activity compared to indomethacin $(10 \mathrm{mg} / \mathrm{kg})$, the standard anti-inflammatory drug, with a decrease in inflammation for up to $90 \mathrm{~min}$ [13]. The dichloromethane, ethyl acetate and aqueous extracts of $R$. vulgaris stem bark, root and leaf have exhibited moderate to toxic toxicity against brine shrimp with $\mathrm{LC}_{50}$ values ranging from $3.55 \mu \mathrm{g} / \mathrm{ml}$ to $734.06 \mu \mathrm{g} / \mathrm{ml}$ while cyclophosphamide, the positive control, demonstrated an $\mathrm{LC}_{50}$ value of $15.28 \mu \mathrm{g} / \mathrm{ml}[12]$.

Plants protect themselves from pathogens through the synthesis of secondary metabolites or bioactive molecules known as phytochemicals which exhibit antimicrobial properties [14]. Phytochemical studies on R. vulgaris have revealed that it contains terpenoids, flavonoids and terpenes [6]. Bioactive compounds are produced by plants in small concentrations, the extraction method and solvents selected are crucial in the discovery of potential antimicrobial agents [15]. Phytochemical extraction depends on the polarity of the solvents used. A single solvent cannot therefore be expected to extract all the phytochemicals [16]. The use of methanol solvent has led to the extraction of the highest concentration of phenolics, terpenoids, flavonoids and alkaloids [17]. Dichloromethane solvent is useful for the extraction of non-polar compounds while water extracts most of the polar compounds [18]. In the Lake Victoria Basin districts of Uganda, $R$. vulgaris fruits, stem bark and leaves are prepared for consumption using water through decoction, steaming or the leaves and fruits eaten raw for the treatment of toothache, malaria and syphilis [8]. In this study aqueous, methanol and methanol:dichloromethane (1:1) solvents will be utilized for extraction purposes to ensure the extraction of all the phytochemicals enabling a comprehensive evaluation of the antimicrobial properties against selected pathogens and a complete toxicological assessment of $R$. vulgaris.

To the best of our knowledge, after conducting extensive research, no studies have been done on the antibacterial, antifungal and cytotoxic activity of $R$. vulgaris in Kenya. Geographical distribution plays a major role in the phytochemical composition of plants [19], hence, provides a good basis for research into the antibacterial, antifungal and cytotoxic properties of $R$. vulgaris growing in Kenya. Additionally, no studies have been reported on acute toxicity and acute dermal irritation of $R$. vulgaris extracts. The in vivo toxicity evaluation of plant extracts is crucial for the establishment of their safety profiles. Acute toxicity assays provide useful information on the safe and lethal dose range of plant extracts [20]. 
This study was designed to provide valuable information on the antimicrobial activity and safety of $R$. vulgaris extracts in order to determine its potential use in the maintenance of oral health.

\section{Methods}

\section{Plant materials}

Rhus vulgaris Meikle stem bark was collected from Mwala Sub-county, Machakos County $\left(1.3520^{\circ}\right.$ S, $37.4503^{\circ}$ E) based on its undocumented use in the maintenance of oral hygiene by the local community and the use of its stem bark to cure toothache in Uganda [8]. The plant species was authenticated by a botanist, Mr. Patrick B. Mutiso, Chief technologist at the School of Biological Sciences, University of Nairobi. A voucher specimen (AMM2016/ 002) deposited at the University of Nairobi Herbarium.

\section{Bacterial cultures}

Clinical isolates of Staphylococcus aureus, Methicillinresistant S. aureus, Streptococcus mutans and Candida albicans were obtained from Centre for Microbiology Research (CMR), Kenya Medical Research Institute (KEMRI).

\section{Cell lines}

Vero E6 cell lines, sourced from American Type Culture Collections (ATTC ${ }^{\circ}$ CRL-1586 ${ }^{\mathrm{Tm}}$ ) and cultured at Centre for Traditional Medicine and Drug Research (CTMDR) KEMRI laboratories, were used in cytotoxicity studies.

\section{Laboratory animals}

Male Wistar rats (150-230 g) were used for the acute dermal irritation/corrosion assay and nulliparous female Swiss albino mice $(18 \mathrm{~g}-26 \mathrm{~g})$ were used for the acute toxicity assay. The animals were obtained from the KEMRI animal house and were kept under standard room conditions. Pelleted feed (Unga Mice Pencils, Unga Feeds Ltd) and water was made available ad libitum. Principles of humane laboratory animal care and use were observed according to the Animal Care and Use Committee (ACUC).

\section{Extraction}

The extraction process was carried out according to $\mathrm{Si}$ mon et al., [21] with slight modifications. The plant samples were washed, cut into small pieces and left to dry for 2 weeks at room temperature away from direct sunlight. The dried plant material was then finely ground using a grinding mill and stored in brown paper bags at room temperature until use. Both aqueous and organic solvent (methanol and methanol:dichloromethane (1:1)) extraction were carried out.

\section{Aqueous extraction}

Distilled water $(400 \mathrm{ml})$ was added to the ground plant materials (100 g) obtained from $R$. vulgaris and placed in a water bath for $1 \mathrm{~h}$ and $30 \mathrm{~min}$ at $60^{\circ} \mathrm{C}$. Upon cooling, the aqueous solution was filtered twice using Whatman No. 1 filter paper. The extracts was then lyophilized using a freeze dryer (Edwards freeze dryer Modulyo) then stored in airtight plastic vials at $4{ }^{\circ} \mathrm{C}$ until use.

\section{Organic solvent extraction}

The ground plant material $(100 \mathrm{~g})$ was soaked in $300 \mathrm{ml}$ of the solvent (methanol; methanol:dichloromethane (1: 1)) for $72 \mathrm{~h}$ then and agitated periodically. The mixture was filtered twice using Whatman ${ }^{\circ}$ No. 1 filter paper. The solvent was then removed under reduced pressure using a rotary evaporator (Büchi Rota vapor R-114). A temperature of $60^{\circ} \mathrm{C}$ and $55^{\circ} \mathrm{C}$ was applied for the methanol and methanol:dichloromethane extracts respectively. Residual solvent was removed by leaving the extracts in the open. The organic extracts were stored in glass vials at $4{ }^{\circ} \mathrm{C}$.

\section{Antimicrobial assay \\ Disc diffusion assay}

The Kirby-Bauer disc diffusion method reported by Thirumurugan [22] was used to determine whether the plant extracts could inhibit the growth of the selected pathogenic bacteria and fungi. Mueller Hinton Agar (OXOID LTD Basingstoke, Hampshire, England) was prepared by dissolving $38 \mathrm{~g} / \mathrm{l}$ in distilled water. Plates were prepared by pouring $15 \mathrm{ml}$ of molten media into sterile petri plates. The molten media was allowed to solidify for $5 \mathrm{~min}$ and the inoculum swabbed uniformly. The culture was then allowed to dry for another $5 \mathrm{~min}$. The same technique was applied using Sabouraud's dextrose agar for fungal species. Sterile discs were impregnated with $20 \mu \mathrm{l}$ of $100 \mathrm{mg} / \mathrm{ml}$ of the plant extracts, allowed to dry slightly and placed on the surface of cultured agar plates. The negative controls used were distilled water for aqueous extracts and 70\% Dimethyl sulfoxide (Sigma) for organic extracts. Standard antibiotic discs of sulfamethoxazole/trimethoprim (23.7/ $1.25 \mu \mathrm{g})$ and fluconazole $(2 \mathrm{mg} / \mathrm{ml})$ were used as positive controls for bacteria and fungi respectively. Bacterial and fungal culture plates were then incubated at $37^{\circ} \mathrm{C}$ for $24 \mathrm{~h}$ and inhibition zones measured in millimeters using a ruler. This assay was performed in duplicate. An indication of significant antibacterial activity was taken to be a growth inhibition zone of $10 \mathrm{~mm}$ and above as applied by the CMR laboratories, where the work was undertaken.

\section{Minimum inhibitory concentration assay}

The Minimum Inhibitory Concentration (MIC) test adapted from Thirumurugan [22] was only performed on the plant extracts that showed significant antimicrobial activity in the disc diffusion method i.e. an average zone of inhibition of $\geq 10 \mathrm{~mm}$. Exactly $20 \mu \mathrm{l}$ of each plant extract was loaded onto a 96-well titer plate and serially 
diluted from a concentration of $100 \mathrm{mg} / \mathrm{ml}$ to $0.05 \mathrm{mg} /$ $\mathrm{ml}$ using sterile tryptic soy broth. Gentamicin $(20 \mu \mathrm{l})$, the positive control, was serially diluted from a concentration of $14 \mathrm{mg} / \mathrm{ml}$ to $0.0068 \mathrm{mg} / \mathrm{ml}$ using sterile tryptic soy broth. Each plant extract was placed in two rows of the microtiter plate for serial dilution. Gentamicin was also placed in two rows of the microtiter plate for serial dilution. The first row served as the test while the second row served as the control. Microbial suspension $(20 \mu \mathrm{l})$ was only added to the first row. A control experiment was carried out simultaneously in the second row using plant extracts/positive control of the same dilutions and no microorganisms. The microtiter plates were incubated at $35^{\circ} \mathrm{C}$ with low humidity overnight.

\section{Minimum bactericidal concentration assay}

The Minimum Bactericidal Concentration (MBC) assay adapted from Sánchez et al., [23] was performed by subculturing the samples from each well of the MIC microtitre plates onto a fresh drug-free solid medium using sterile swabs. The petri dishes were then incubated overnight. Lack of visible growth was taken as an indication of the bactericidal ability at the particular concentration of the plant extract. From the results of the MBC and $\mathrm{MIC}$ assays, the MBC/MIC ratio was calculated to determine the bactericidal and bacteriostatic properties of active extracts recorded based on Konaté et al., [24] where if the $\mathrm{MBC} / \mathrm{MIC}$ ratio is $\leq 4.0$, the test substance is considered bactericidal, and when the $\mathrm{MBC} / \mathrm{MIC}$ ratio is > 4.0 it is considered bacteriostatic.

\section{Cytotoxicity}

The 3-(4,5-dimethylthiazol-2-yl)-2,5-diphenyltetrazolium bromide (MTT, Sigma, USA) assay reported by Radol et al., [25] was used to determine the cytotoxic effects of the plant extracts on Vero cell lines. The cells were cultured in T-75 cell culture flasks and incubated in Eagle's Minimum Essential Medium (MEM) with 10\% fetal bovine serum (FBS) at $37^{\circ} \mathrm{C}$ in $5 \% \mathrm{CO}_{2}$. After a confluent cell sheet was achieved, it was dissociated using trypsin and the cells pooled in a $50 \mathrm{ml}$ tube. MEM $(40 \mathrm{ml})$ was added forming a cellular suspension of which a $100 \mu \mathrm{l}$ of cell suspension containing $2 \times 10^{5}$ cells was seeded in 96-well microtiter plates. In row $\mathrm{H}, 150 \mu \mathrm{l}$ of $100 \mu \mathrm{g} / \mathrm{ml}$ DMSO of the highest test sample concentration in duplicate, was pipetted. DMSO was used to solubilize the organic plant extracts. Serial dilutions were conducted by pipetting $50 \mu \mathrm{l}$ from wells of row $\mathrm{H}$ and adding to wells of row G. Another $50 \mu \mathrm{l}$ was transferred from row $\mathrm{G}$ to wells of row F up to row B discarding the last $50 \mu \mathrm{l}$ of this row. A threefold dilution was performed from row $\mathrm{H}$ to $\mathrm{B}$ wells. Incubation was conducted for $48 \mathrm{~h}$ at $37^{\circ} \mathrm{C}$ in $5 \% \mathrm{CO}_{2}$ allowing the effect of the test sample on the cells to occur. Cells were observed under the inverted microscope. Into each well, $10 \mu \mathrm{l}$ of MTT dye was added for the colorimetric determination of viable cells. Cells were further incubated for another $4 \mathrm{~h}$ at $37{ }^{\circ} \mathrm{C}$ in $5 \% \mathrm{CO}_{2}$. Media was removed from the wells and $100 \mu \mathrm{l}$ of DMSO (Sigma) added to solubilize the formazan. Reading of the plates was performed on a scanning multiwell spectrophotometer (Multiskan Ex labsystems) at $562 \mathrm{~nm}$ and $620 \mathrm{~nm}$ as reference. Doxorubicin $(50 \mu \mathrm{g} / \mathrm{ml}$ highest drug concentration) was used as a positive control.

\section{Acute dermal irritation/corrosion assay}

The acute dermal irritation/corrosion test was conducted as recommended by the Organisation for Economic Cooperation and Development (OECD) Guideline 404, 2002 according to Mengiste et al., [26] with modifications from Pinto et al., [27]. Rats were used for this test. The animals were randomly selected, marked and placed in cages 5 days prior to the commencement of the test to facilitate acclimatization. Approximately $24 \mathrm{~h}$ before the test began, the rats were restrained and an area of approximately 3 $\mathrm{cm}^{2}$ shaved using an electric shaver. Any residual hair was removed using a hair removal cream. Exactly $0.5 \mathrm{~g}$ of plant extract in $2 \mathrm{ml}$ of $10 \%$ polysorbate 80 (Tween ${ }^{\circ} 80$ ) was applied to the cotton gauze, placed in contact with the animal's skin and held in place with hypoallergenic tape. One rat was used as the control, to which $10 \%$ polysorbate 80 was applied. After $4 \mathrm{~h}$, the test substance/control was removed. All animals were examined for signs of erythema and oedema, and the responses scored at $60 \mathrm{~min}$, and then at 24,48 and $72 \mathrm{~h}$ after removal of the test substance. The initial test was performed on one animal. If a corrosive effect was not observed in the initial test, the negative response was confirmed using two additional animals, each with one patch. The animals were observed for 14 days to record the occurrence and reversibility of any irritant/corrosive effects. They were then euthanized using $\mathrm{CO}_{2}$, placed in biohazard bags and incinerated.

\section{Acute toxicity assay}

The acute toxicity assay was conducted in mice as recommended by the OECD Guideline 423,2001 according to Alhaddad et al., [28] with minor modifications. Female, nulliparous, 8 weeks old Swiss albino mice were used. Animals were randomly selected, marked and placed in cages 5 days prior to the commencement of this test to facilitate acclimatization. Three mice were placed into each cage and a single dose of the test substance administered orally via canula. A starting dose level used was $50 \mathrm{mg} / \mathrm{kg}$ followed by $300 \mathrm{mg} / \mathrm{kg}$ and then $2000 \mathrm{mg} / \mathrm{kg}$ body weight. Food was withheld for $2 \mathrm{~h}$ before and $30 \mathrm{~min}$ after administration of the test substance. Treatment of animals at the next dose was delayed for $24 \mathrm{~h}$ to assure the survival of the previously 
dosed animals. Animals were observed during the first 4 $\mathrm{h}$, and daily thereafter, for a total of 14 days. Clinical signs and mortality cases were recorded. During the 2 week study period, the mice were weighed before oral administration and every seventh day thereafter. On the 14th day after administration of the test substance, the animals were euthanized using $\mathrm{CO}_{2}$ and subjected to gross necropsy. All gross pathological changes were recorded for each animal. Afterwards, they were placed in biohazard bags and incinerated.

\section{Phytochemical screening}

Since the methanol extracts were the most active in the bioassays, they were subjected to phytochemical screening to detect secondary metabolites using standard qualitative procedures as performed by Gul et al., [29] for glycosides, Fayaz et al., [30] for alkaloids and Anthoney [31] for tannins, saponins, flavonoids, terpenoids, steroids and phenols. Photographs of the color change and tables were used to document the results.

\section{Tannins}

A $0.5 \mathrm{~g}$ sample of the crude extract was put in a test tube and $20 \mathrm{ml}$ of distilled water added to it then heated to boiling. The mixture was then filtered and $1 \%$ of $\mathrm{FeCl}_{3}$ added to the filtrate and observations made. A brownish green coloration indicated the presence of tannins.

\section{Saponins}

The crude plant extract was mixed with $5 \mathrm{ml}$ of water and vigorously shaken. The formation of stable persistent froth indicated the presence of saponins.

\section{Flavonoids}

A portion of the crude extract was added into a test tube. To this, $5 \mathrm{ml}$ of dilute ammonia and $2 \mathrm{ml}$ of concentrated sulfuric acid were added. The appearance of a yellow color indicated the presence of flavonoids.

\section{Terpenoids}

To the plant extracts, $2 \mathrm{ml}$ of chloroform was added and vigorously shaken and then evaporated to dryness. To this, $2 \mathrm{ml}$ of concentrated sulfuric acid was added and heated for about $2 \mathrm{~min}$. A greyish color indicated the presence of terpenoids.

\section{Glycosides}

Salkowski's test: The extract of the plant material was mixed with $2 \mathrm{ml}$ of chloroform and then $2 \mathrm{ml}$ of concentrated sulfuric acid added carefully and shaken gently. A reddish brown color indicated the presence of the steroidal (steroidal aglycone) part of glycosides.

\section{Alkaloids}

A few drops of Dragendorff's reagent was added into the test tube containing crude extracts. The resulting yellow precipitate indicated the presence of alkaloids.

\section{Steroids}

Liebermann Burchard reaction: About $2 \mathrm{~g}$ of the extract was put in a test tube and $10 \mathrm{ml}$ of chloroform added, filtered and then $2 \mathrm{ml}$ of the filtrate mixed with $2 \mathrm{ml}$ of a mixture of acetic acid and then concentrated sulfuric acid was added along the side of the test tube. Blue green ring indicated the presence of steroids.

\section{Phenols}

The plant extract $(3 \mathrm{ml})$ was put into a test tube and treated with 1-2 drops of $2 \%$ of $\mathrm{FeCl}_{3}$. Formation of bluish green coloration indicated the presence of phenols.

\section{Data analysis}

In antimicrobial screening, one-way ANOVA and Tukey's multiple comparisons tests were performed using IBM SPSS statistics 20.0. The means and the standard deviations were derived from the zones of inhibition to determine statistical significance ( $p$-value < 0.05). In cytotoxicity testing, one-way ANOVA and Dunnett's multiple comparison tests were conducted using GraphPad Prism 8.0. Percentage cell viability was derived from absorbance readings in MS Excel data sheets and used to calculate the half maximal inhibitory concentration $\left(\mathrm{IC}_{50}\right)$ using dose-response curves. Statistical significance $(p$-value $<0.05)$ was established through the comparison of the percentage cell viability after exposure of the cells to the extracts and the standard reference drug. In acute dermal corrosion testing, photographs were taken to document hair growth rate and any skin reactions. In acute toxicity testing, one-way ANOVA and Tukey's multiple comparison tests were calculated using IBM SPSS statistics 20.0. Comparisons were made between the sample mean weights and control mean weights to establish statistical significance $(p \leq 0.05)$.

\section{Results}

\section{Antimicrobial assay}

Table 1 shows the results of the microbial growth inhibition by $R$. vulgaris against MRSA, S. aureus, S. mutans and $C$. albicans. The organic extracts of $R$. vulgaris exhibited higher antimicrobial activity compared to the aqueous extracts. Among the organic extracts, methanol extracts demonstrated greater zones of inhibition. The most susceptible microorganism was $S$. aureus followed by MRSA, $S$. mutans and lastly, C. albicans with little to no inhibition observed. The $\mathrm{MeOH}$ ( $p$-value of 0.722 ) and $\mathrm{MeOH}: \mathrm{DCM}$ ( $p$-value of 0.069$)$ extracts resulted in 
Table 1 Growth inhibition of microorganisms by R. vulgaris extracts

\begin{tabular}{|c|c|c|c|c|c|}
\hline Microorganism & Plant & Plant part & Solvent & $\begin{array}{l}\text { Average Zone of inhibition } \\
\pm \text { Std. dev. of duplicates (mm) }\end{array}$ & $\overline{p \text {-values }}$ \\
\hline MRSA & R. vulgaris & Stem bark & $\mathrm{MeOH}$ & $12.00 \pm 0.00$ & $<0.005$ \\
\hline MRSA & R. vulgaris & Stem bark & MeOH:DCM & $10.00 \pm 0.00$ & $<0.005$ \\
\hline MRSA & R. vulgaris & Stem bark & Aqueous & $7.00 \pm 0.00$ & 0.039 \\
\hline MRSA & Control & & & $6.00 \pm 0.00$ & \\
\hline S. aureus & R. vulgaris & Stem bark & $\mathrm{MeOH}$ & $19.50 \pm 0.71$ & 0.722 \\
\hline S. aureus & R. vulgaris & Stem bark & $\mathrm{MeOH}: \mathrm{DCM}$ & $17.00 \pm 2.83$ & 0.069 \\
\hline S. aureus & R. vulgaris & Stem bark & Aqueous & $7.00 \pm 0.00$ & $<0.005$ \\
\hline S. aureus & Control & & & $24.19 \pm 3.60$ & \\
\hline S. mutans & R. vulgaris & Stem bark & $\mathrm{MeOH}$ & $10.00 \pm 0.00$ & $<0.005$ \\
\hline S. mutans & R. vulgaris & Stem bark & MeOH:DCM & $10.00 \pm 0.00$ & $<0.005$ \\
\hline S. mutans & R. vulgaris & Stem bark & Aqueous & $9.00 \pm 0.00$ & $<0.005$ \\
\hline S. mutans & Control & & & $22.13 \pm 3.44$ & \\
\hline C. albicans & R. vulgaris & Stem bark & $\mathrm{MeOH}$ & $6.50 \pm 0.00$ & $<0.005$ \\
\hline C. albicans & R. vulgaris & Stem bark & MeOH:DCM & $6.00 \pm 0.00$ & $<0.005$ \\
\hline C. albicans & R. vulgaris & Stem bark & Aqueous & $6.50 \pm 0.00$ & $<0.005$ \\
\hline C. albicans & Control & & & $38.13 \pm 4.86$ & \\
\hline
\end{tabular}

MRSA Methicillin-resistant Staphylococcus aureus, S. aureus: Staphylococcus aureus, C. albicans: Candida albicans, S. mutans: Streptococcus mutans, R. vulgaris: Rhus vulgaris, $\mathbf{M e O H}$ Methanol, MeOH:DCM Methanol:Dichloromethane. The positive control for MRSA, S. aureus and S. mutans was sulfamethoxazole/ trimethoprim $(23.7: 1.25 \mu \mathrm{g})$ standard antimicrobial discs. Plant extract concentration was $100 \mathrm{mg} / \mathrm{ml}$. The positive control for C. albicans was fluconazole at a concentration of $2 \mathrm{mg} / \mathrm{ml}$. $p$-values of $\leq 0.05$ demonstrate statistical significance

zones of inhibition of $19.50 \mathrm{~mm}$ and $17.00 \mathrm{~mm}$ respectively against S. aureus. The Methanol $(10 \mathrm{~mm})$ and $\mathrm{MeOH}$ : DCM $(10 \mathrm{~mm}) R$. vulgaris extracts gave slightly greater zones of inhibition against $S$. mutans than the aqueous extracts $(9 \mathrm{~mm})$, with a $p$-value of $<0.005$ (Fig. 1, Plate 1 ).

$R$. vulgaris methanol extracts showed inhibitory and bactericidal activity against MRSA $(0.391 \mathrm{mg} / \mathrm{ml}$ and $1.563 \mathrm{mg} / \mathrm{ml})$, S. aureus $(3.125 \mathrm{mg} / \mathrm{ml}$ and $3.125 \mathrm{mg} / \mathrm{ml})$ and $S$. mutans $(1.563 \mathrm{mg} / \mathrm{ml}$ and $100 \mathrm{mg} / \mathrm{ml})$ with $\mathrm{MIC}$ and $\mathrm{MBC}$ values, respectively. The MeOH:DCM extracts also demonstrated antibacterial properties against MRSA $(1.563 \mathrm{mg} / \mathrm{ml}, 3.125 \mathrm{mg} / \mathrm{ml}), \quad$ S. aureus $(3.125 \mathrm{mg} / \mathrm{ml}$, $12.5 \mathrm{mg} / \mathrm{ml}$ ) and $S$. mutans $(25 \mathrm{mg} / \mathrm{ml}, 100 \mathrm{mg} / \mathrm{ml})$ with $\mathrm{MIC}$ and $\mathrm{MBC}$ values, respectively. Gentamicin, the positive control, also demonstrated antibacterial properties against MRSA $(0.027 \mathrm{mg} / \mathrm{ml}, 0.055 \mathrm{mg} / \mathrm{ml})$, S. aureus $(<0.014 \mathrm{mg} / \mathrm{ml}, 0.109 \mathrm{mg} / \mathrm{ml})$ and $S$. mutans $(0.007 \mathrm{mg} / \mathrm{l}$, $0.027 \mathrm{mg} / \mathrm{ml}$ ) with $\mathrm{MIC}$ and $\mathrm{MBC}$ values, respectively (Table 2). According to Konate et al., [24], if the MBC/ $\mathrm{MIC}$ ratio is $\leq 4.0$, the substance is considered bactericidal, and if the MBC/MIC ratio is $>4.0$, the test substance is considered to be bacteriostatic. Based on the MBC/MIC ratio (Table 2), it was established that the $R$. vulgaris methanol extracts were bactericidal against MRSA and S. aureus. $R$. vulgaris methanol extracts were bacteriostatic against $S$. mutans. The MeOH:DCM stem bark extracts were bactericidal against MRSA, S. aureus and S. mutans while gentamicin, the positive control, was bactericidal against MRSA and S. mutans (Fig. 1, Plate 2).

\section{Cytotoxicity}

Figure 2 \& Fig. 3 are graphical representations of the percentage cell viability after exposure to different concentrations of $R$. vulgaris extracts and doxorubicin, the standard reference drug.

The MTT assay performed using Vero cells generated $\mathrm{IC}_{50}$ values of $1120 \mu \mathrm{g} / \mathrm{ml}$ and $16.37 \mu \mathrm{g} / \mathrm{ml}$ for the MeOH:DCM extracts of $R$. vulgaris and doxorubicin (Fig. 3). The methanol $R$. vulgaris extracts ( $p$-value of 0.0039) supported the proliferation of cells and showed no cytotoxic properties in the tested concentrations (Fig. 2). Marginal cytotoxic properties developed as the $\mathrm{MeOH}: \mathrm{DCM}$ extract ( $p$-value of 0.1173 ) concentration increased (Fig. 3).

\section{Acute dermal irritation/corrosion}

A visual representation of the effects of $R$. vulgaris exposure on the dermis of Wistar rats is displayed in Fig. 4. $R$. vulgaris demonstrated a noteworthy skin reaction in one out of the three rats used. After exposure, the skin of rat one of the rats showed slight erythema after $4 \mathrm{~h}$ followed by moderate erythema and flaking of the skin after $24 \mathrm{~h}$. The skin reaction resolved within 8 days. 


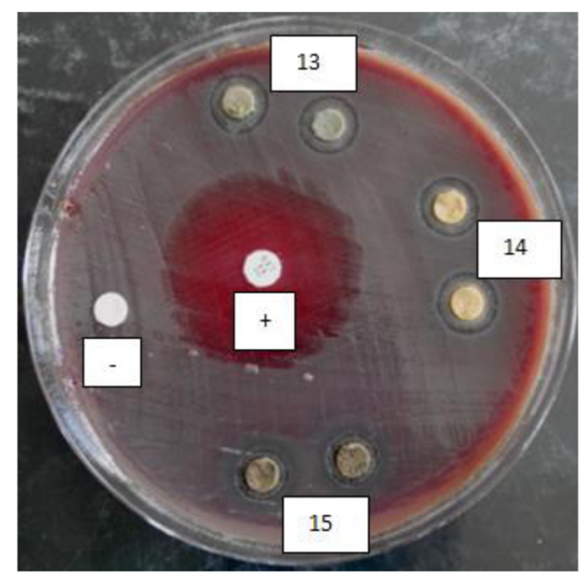

A

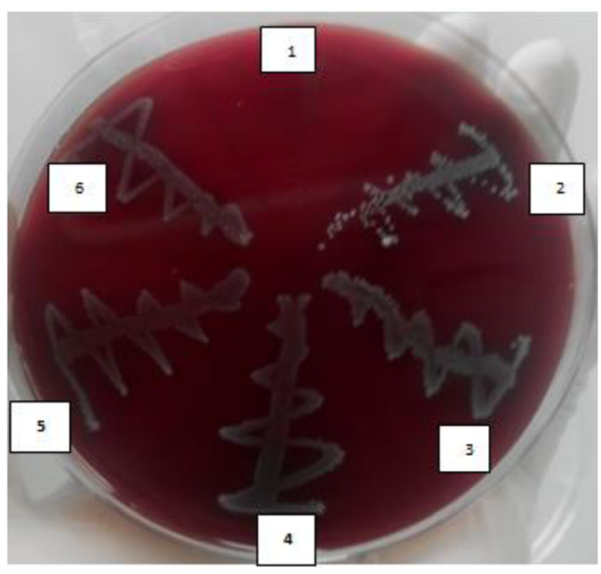

B

Fig. 1 Disc diffusion and MIC plates of $R$. vulgaris extracts against S. mutans on Blood agar. a: 13:MeOH extracts, 14:MeOH:DCM extracts, 15:Aqueous extracts; +:positive control and -:negative control. b: 1:MeOH extracts at concentrations of 100 mg/ml, 2:50 mg/ml, 3:25 mg/ml, 4:12.5 mg/ml, 5:6.25 $\mathrm{mg} / \mathrm{ml}$ and $\mathbf{6 :} 3.125 \mathrm{mg} / \mathrm{ml}$

\section{Acute oral toxicity}

The oral administration of $R$. vulgaris at a concentration of $300 \mathrm{mg} / \mathrm{kg}$ resulted in hunched posture, inactivity, piloerection and tachypnea in 2 out of 3 mice while at concentrations of $50 \mathrm{mg} / \mathrm{kg}$ and $2000 \mathrm{mg} / \mathrm{kg}$ no changes in general appearance and behavioral patterns were noted. After $24 \mathrm{~h}$, the general appearance and behavioral patterns of all the mice were normal. The weights recorded on the 1st, 7th and 14th day were not statistically significant $(p$-value $>0.05)$ when compared to the controls (Table 3, Fig. 5). There was no mortality or gross pathology in any organ at necropsy.

\section{Phytochemical screening}

Phytochemical screening was performed to determine the bioactive compounds present in the extract which tested positive for tannins, saponins, flavonoids, terpenoids, glycosides, alkaloids and phenols are shown in Table 4 . Steroids were not detected.

\section{Discussion}

In the world millions of people are afflicted by oral diseases [32] through biofilm development [33]. If preventive or curative measures are not undertaken against oral pathogens, systemic or chronic diseases such as diabetes, osteoporosis, rheumatoid arthritis and coronary heart disease may result [33]. The number of oral bacteria in healthy individuals is in the range $10^{2}-10^{3}, 10^{4}-10^{8}$ in a gingival state and $10^{5}-10^{8}$ in a periodontal state [34].

The tested $R$. vulgaris extracts demonstrated significant antimicrobial activity against some pathogens that cause oral infections. The methanol extract showed the highest activity followed by the MeOH:DCM extract and lastly, the aqueous extract with the least activity. The methanol $(12 \mathrm{~mm})$ and $\mathrm{MeOH}: \mathrm{DCM}(10 \mathrm{~mm})$ extracts of

Table 2 The MIC and MBC values of active plant extracts

\begin{tabular}{|c|c|c|c|c|c|c|}
\hline Microorganism & Plant/ test substance & Plant part & Solvent & $\mathrm{MIC} \mathrm{mg} / \mathrm{ml}$ & $\mathrm{MBC} \mathrm{mg} / \mathrm{ml}$ & MBC/MIC Ratio \\
\hline MRSA & R. vulgaris & Stem bark & $\mathrm{MeOH}$ & 0.391 & 1.563 & 4 \\
\hline MRSA & R. vulgaris & Stem bark & MeOH:DCM & 1.563 & 3.125 & 2 \\
\hline MRSA control & Gentamicin & & & 0.027 & 0.055 & 2 \\
\hline S. aureus & R. vulgaris & Stem bark & $\mathrm{MeOH}$ & 3.125 & 3.125 & 1 \\
\hline S. aureus & R. vulgaris & Stem bark & MeOH:DCM & 3.125 & 12.5 & 4 \\
\hline S. aureus control & Gentamicin & & & $<0.014$ & 0.109 & NA \\
\hline S. mutans & R. vulgaris & Stem bark & $\mathrm{MeOH}$ & 1.563 & 100 & 64 \\
\hline S. mutans & R. vulgaris & Stem bark & $\mathrm{MeOH}: \mathrm{DCM}$ & 25 & 100 & 4 \\
\hline S. mutans control & Gentamicin & & & 0.007 & 0.027 & 4 \\
\hline
\end{tabular}

NA Not applicable, MRSA Methicillin-resistant Staphylococcus aureus, S. aureus: Staphylococcus aureus, C. albicans: Candida albicans, S. mutans: Streptococcus mutans, R. vulgaris: Rhus vulgaris, MeOH Methanol, MeOH:DCM Methanol:Dichloromethane, The positive control for MRSA, S. aureus and S. mutans was gentamicin 


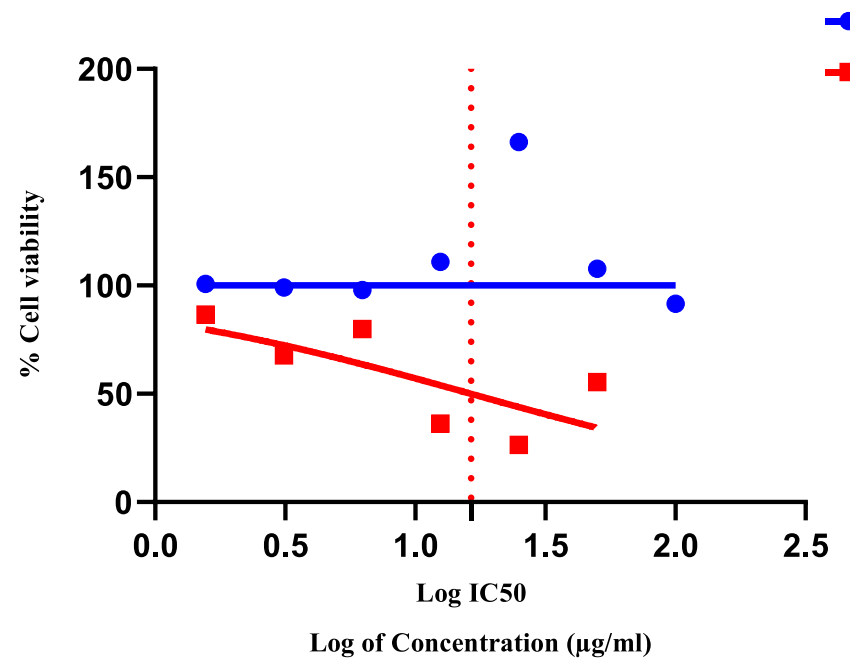

Fig. 2 Cytotoxic activities of methanol extract of $R$. vulgaris (SB) and Doxorubicin against Vero cells. R. vulgaris methanol extract concentration ranged from $100 \mu \mathrm{g} / \mathrm{ml}$ to $1.5625 \mu \mathrm{g} / \mathrm{ml}$. Doxorubicin concentration ranged from $50 \mu \mathrm{g} / \mathrm{ml}$ to $0.78125 \mu \mathrm{g} / \mathrm{ml}$. Doxorubicin exhibited an IC50 value of $16.37 \mu \mathrm{g} / \mathrm{ml}$

R. vulgaris demonstrated the greatest growth inhibition against MRSA with a $p$ value of $<0.005$. Furthermore, the methanol and MeOH:DCM $R$. vulgaris extracts also showed antibacterial activity against $S$. mutans with a mean diameter zone of inhibition of $10 \mathrm{~mm}$. Very slight anti-streptococcal activity was demonstrated by the aqueous extracts $(7 \mathrm{~mm})$. Different results were obtained by Odongo et al., [9]. The authors reported that aqueous extracts of $R$. vulgaris showed significant antistreptococcal activity $(24 \mathrm{~mm})$. The inactivity recorded in this study compared to its significant activity in the study by Odongo et al., [9] may be due to variations in phytochemical concentrations as a result of differences in plant factors e.g. age at harvesting as well as other ecological factors [35].
Traditional medicine has been applied in combating antimicrobial resistance [36]. For instance, the stem bark of $R$. vulgaris is traditionally used in the treatment of toothaches [8] supporting its activity against S. mutans. Furthermore, extracts of $R$. vulgaris were bactericidal against MRSA and $S$. aureus. MeOH:DCM extracts of $R$. vulgaris were bactericidal while methanol extracts were bacteriostatic against $S$. mutans. The MIC and MBC values of $R$. vulgaris methanol extracts were $\leq 3.13 \mathrm{mg}$ / $\mathrm{ml}$ against $S$. aureus and MRSA.

In cytotoxicity testing, MeOH:DCM extracts of $R$. vulgaris exhibited marginal inhibition of proliferation against Vero cells while the methanol extracts supported cellular proliferation. Application of a single oral dose of $R$. vulgaris up to $2000 \mathrm{mg} / \mathrm{kg}$ resulted in no observable

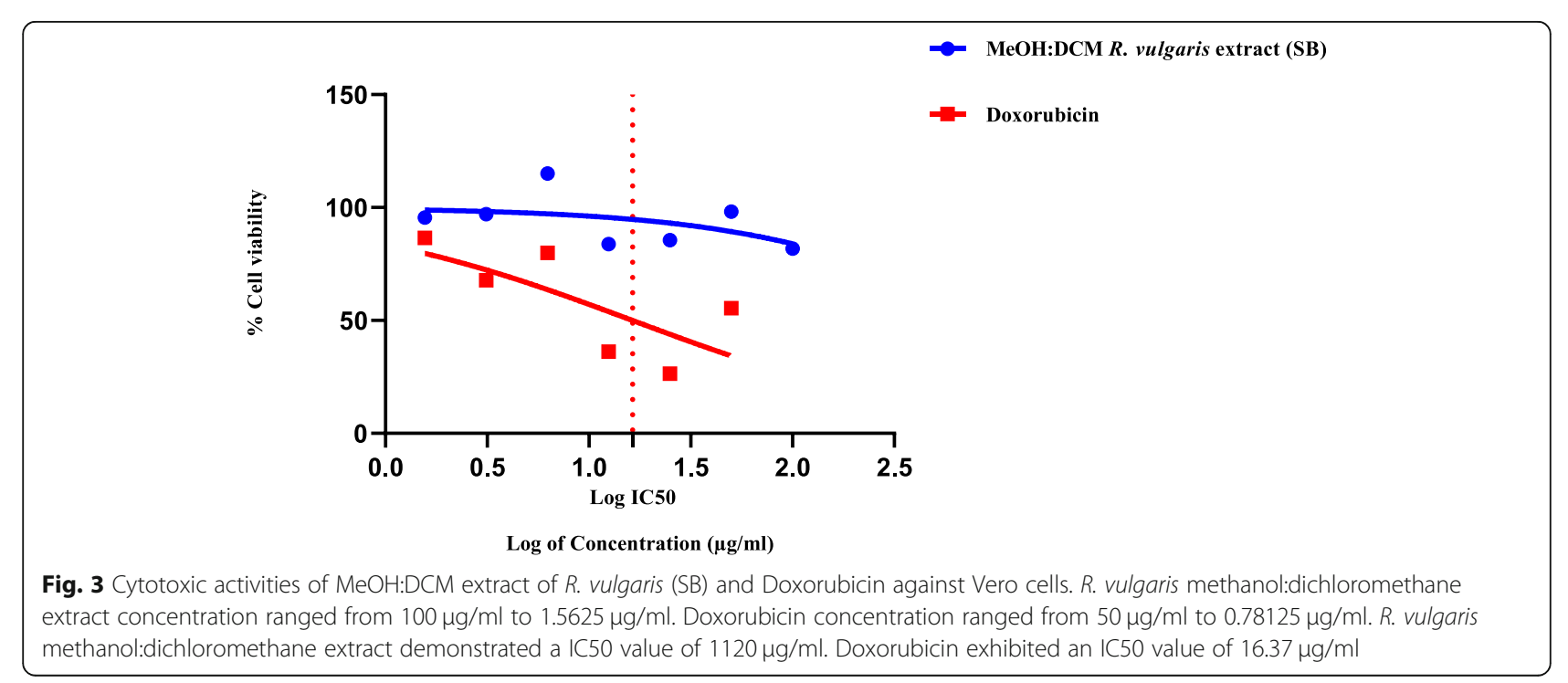




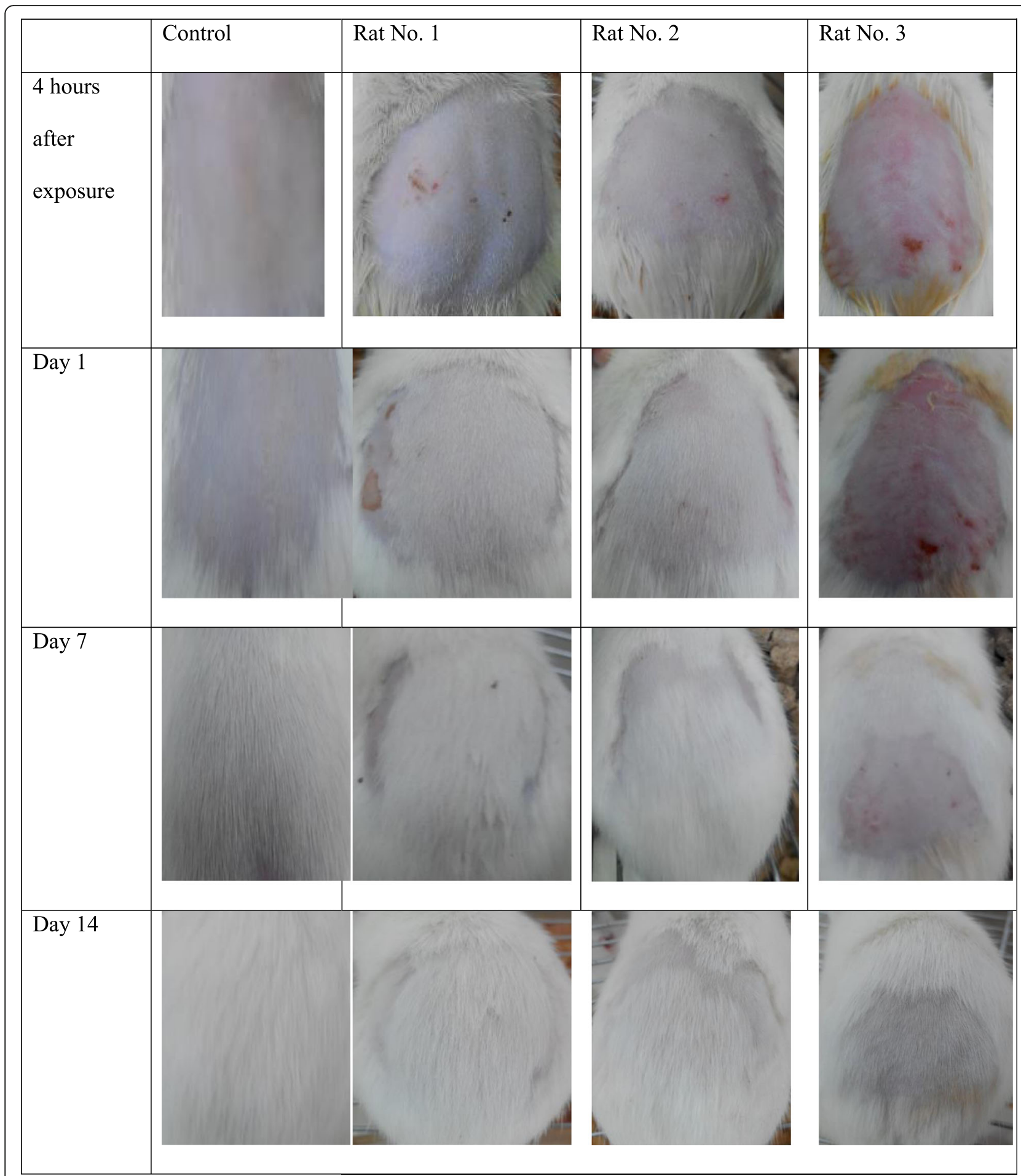

Fig. 4 The effects of the exposure of $R$. vulgaris extracts on the depilated skin of Wistar rats

adverse effects in the test subjects. Further, no manifestations of toxicity were detected during gross pathology. As far as we know, there are no previous studies on the acute toxicity testing of $R$. vulgaris extracts in mice. The observations from this study, in addition to the history of traditional use are an indication of the safety of $R$. vulgaris. Moreover, dermal application of $R$. vulgaris (SB) methanol extracts resulted in mild erythema and scaling. Reversibility of the skin reactions was achieved by the 8th day of the study. Dermal application of the extract 
Table 3 Weights of Mice used in Acute Toxicity assay for Day 1, 7 and 14

\begin{tabular}{|c|c|c|c|c|c|c|c|c|c|c|}
\hline \multirow[t]{2}{*}{ Plant extracts } & \multirow{2}{*}{$\begin{array}{l}\text { Concentration } \\
(\mathrm{mg} / \mathrm{kg})\end{array}$} & \multirow[t]{2}{*}{ Cage } & \multirow[t]{2}{*}{ Day 1} & \multirow[t]{2}{*}{ Day 7} & \multirow[t]{2}{*}{ Day 14} & \multirow[t]{2}{*}{ Mean \pm} & \multirow{2}{*}{$\begin{array}{l}\text { Standard } \\
\text { Deviation }\end{array}$} & \multicolumn{3}{|c|}{ Significance } \\
\hline & & & & & & & & Control 1 & Control 2 & Control 3 \\
\hline Control 1 & $\mathrm{DH}_{2} \mathrm{O}$ & $C 1^{\mathrm{a}}$ & 20 & 20 & 22 & 20.6667 & 1.15470 & NA & 0.356 & 1.000 \\
\hline Control 2 & $\mathrm{DH}_{2} \mathrm{O}$ & $C 2^{b}$ & 24 & 25 & 26 & 25.0000 & 1.00000 & 0.356 & NA & 0.983 \\
\hline Control 3 & $\mathrm{DH}_{2} \mathrm{O}$ & $C 3^{c}$ & 20 & 22 & 25 & 22.3333 & 2.51661 & 1.000 & 0.983 & NA \\
\hline R. vulgaris & 50 & R.v. $1^{a}$ & 22 & 22 & 24 & 22.6667 & 1.15470 & 1.000 & 0.997 & 1.000 \\
\hline R. vulgaris & 50 & R.v. $1^{\text {b }}$ & 22 & 22 & 23 & 22.3333 & 0.57735 & 1.000 & 0.983 & 1.000 \\
\hline R. vulgaris & 50 & R.v. $1^{c}$ & 25 & 25 & 26 & 25.3333 & 0.57735 & 0.225 & 1.000 & 0.936 \\
\hline R. vulgaris & 300 & R.v. $2^{a}$ & 24 & 25 & 26 & 25.0000 & 1.00000 & 0.356 & 1.000 & 0.983 \\
\hline R. vulgaris & 300 & R.v. $2^{b}$ & 24 & 22 & 25 & 23.6667 & 1.52753 & 0.936 & 1.000 & 1.000 \\
\hline R. vulgaris & 300 & R.v. $2^{c}$ & 22 & 23 & 24 & 23.0000 & 1.00000 & 0.997 & 1.000 & 1.000 \\
\hline R. vulgaris & 2000 & R.v. $3^{a}$ & 21 & 23 & 25 & 23.0000 & 2.00000 & 0.997 & 1.000 & 1.000 \\
\hline R. vulgaris & 2000 & R.v. $3^{b}$ & 24 & 25 & 28 & 25.6667 & 2.08167 & 0.132 & 1.000 & 0.838 \\
\hline R. vulgaris & 2000 & R.v. $3^{c}$ & 21 & 22 & 24 & 22.3333 & 1.52753 & 1.000 & 0.983 & 1.000 \\
\hline
\end{tabular}

There were four cages. One cage had the control group while the other three had the test groups. Each cage had 3 mice. All the mice in one cage received the same concentration of control/plant extract. $\boldsymbol{R}$. vulgaris: Rhus vulgaris, $\mathbf{D H}_{\mathbf{2}} \mathbf{O}$ : Distilled water, C 1: Control 1, C 2: Control 2, C 3: Control 3, a: Mouse No.1, b: Mouse No. ${ }^{\prime}{ }^{\text {c: }}$ : Mouse No. 3, R.v. $1^{\text {a }}$ : Oral dose of Rhus vulgaris $(50 \mathrm{mg} / \mathrm{kg})$ administered to Mouse No. 1, R.v. $\mathbf{1}^{\mathbf{b}}$ : Oral dose of $R$. vulgaris (50 mg/kg) administered to Mouse No. 2, R.v. $1^{\text {c }}$ : Oral dose of $R$. vulgaris $\left(50 \mathrm{mg} / \mathrm{kg}\right.$ ) administered to Mouse No. 3, R.v. $2^{\text {a }}$ : Oral dose of $R$. vulgaris (300 mg/kg) administered to Mouse No. 1 , R.v. $\mathbf{2}^{\mathbf{b}}$ : Oral dose of $R$. vulgaris (300 mg/kg) administered to Mouse No. 2, R.v. $\mathbf{2}^{\mathbf{b}}$ : Oral dose of $R$. vulgaris (300 mg/kg) administered to Mouse No. 2, R.v. $\mathbf{2}^{\mathbf{c}}$ : Oral dose of $R$. vulgaris (300 mg/kg) administered to Mouse No. 3, R.v. $3^{\mathbf{a}}$ : Oral dose of $R$. vulgaris (2000 mg/kg) administered to Mouse No. 1, R.v. $3^{\mathbf{b}}$ : Oral dose of $R$. vulgaris $(2000 \mathrm{mg} / \mathrm{kg})$ administered to Mouse No. 2, R.v. $3^{\text {c }}$ : Oral dose of R. vulgaris $(2000 \mathrm{mg} / \mathrm{kg})$ administered to Mouse No. 1, NA: Not applicable

additionally resulted in a slower rate of hair regrowth. Similarly, there are no prior reports on the dermal safety of $R$. vulgaris in laboratory animals.

Natural phytochemicals derived from plants provide an affordable and safer means of treating oral diseases [2]. The use of secondary metabolites isolated from medicinal plants in the development of drugs has helped in the fight against microbial infections [36]. Alkaloids, glycosides, saponins, terpenoids, phenols, tannins and flavonoids were present in $R$. vulgaris extracts while steroids and anthraquinones were not detected. Rayne \& Mazza [6] also detected similar phytochemicals. Methanol extracts of $R$. vulgaris demonstrated significant inhibitory and bacteriostatic activity against $S$. mutans supporting its traditional use in the treatment of toothache. Further investigations on the cause of delayed hair

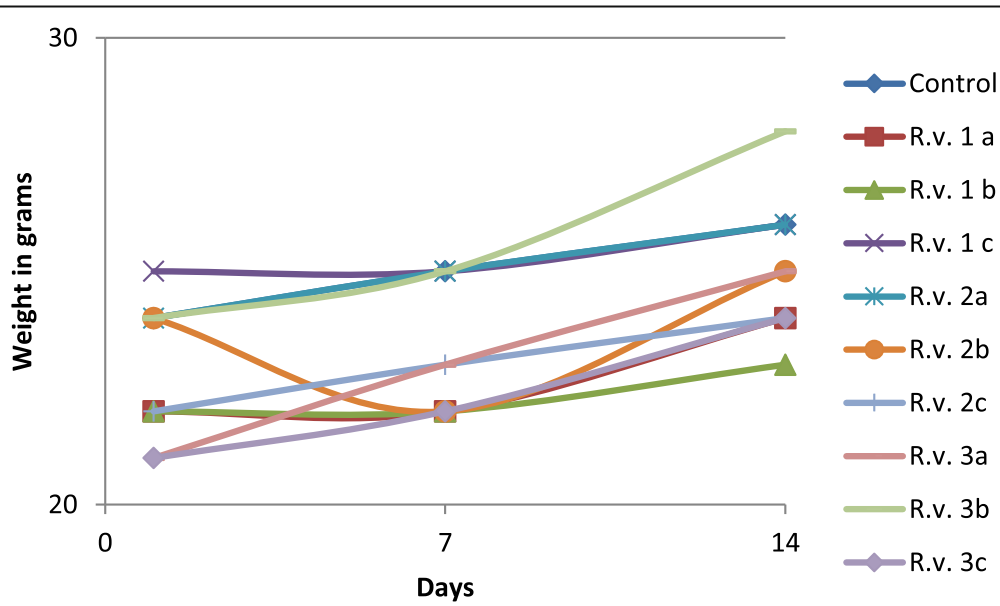

Fig. 5 Weight of mice Weights of Mice used in Acute Toxicity assay for Day 1, 7 and 14. R. vulgaris: Rhus vulgaris, ${ }^{a}:$ Mouse No.1, ${ }^{\mathbf{b}}:$ Mouse No. 2, ${ }^{\mathbf{c}}$ : Mouse No. 3, R.v. $1^{\text {a }}$ : Oral dose of Rhus vulgaris (50 mg/kg) administered to Mouse No. 1, R.v. $1^{\text {b}}$ : Oral dose of R. vulgaris (50 mg/kg) administered to Mouse No. 2, R.v. $1^{\text {c }}$ : Oral dose of R. vulgaris $(50 \mathrm{mg} / \mathrm{kg})$ administered to Mouse No. 3, R.v. $2^{\text {a }}$ : Oral dose of $R$. vulgaris (300 mg/ $\mathrm{kg}$ ) administered to Mouse No. 1, R.v. $\mathbf{2}^{\mathbf{b}}$ : Oral dose of R. vulgaris $\left(300 \mathrm{mg} / \mathrm{kg}\right.$ ) administered to Mouse No. 2, R.v. $\mathbf{2}^{\mathbf{b}}$ : Oral dose of R. vulgaris (300 $\mathrm{mg} / \mathrm{kg}$ ) administered to Mouse No. 2, R.v. $\mathbf{2}^{\mathbf{c}}$ : Oral dose of $R$. vulgaris $(300 \mathrm{mg} / \mathrm{kg})$ administered to Mouse No. 3, R.v. $3^{\mathbf{a}}$ : Oral dose of $R$. vulgaris $(2000 \mathrm{mg} / \mathrm{kg})$ administered to Mouse No. 1, R.v. $3^{\mathbf{b}}$ : Oral dose of $R$. vulgaris $(2000 \mathrm{mg} / \mathrm{kg})$ administered to Mouse No. 2, R.v. $\mathbf{3}^{\text {c }}$ : Oral dose of $R$. vulgaris $(2000 \mathrm{mg} / \mathrm{kg})$ administered to Mouse No. 1 
Table 4 Phytochemical screening of $R$. vulgaris methanol extracts

\begin{tabular}{lll}
\hline Phytochemicals & Reagents & Methanol extract \\
\hline Tannins & Iron (III) chloride & + \\
Saponins & Frothing test & + \\
Flavonoids & Ammonia, Sulfuric acid & + \\
Terpenoids & Chloroform, sulfuric acid & + \\
Glycosides & Chloroform, sulfuric acid & + \\
Alkaloids & Dragendorf's & + \\
Steroids & Chloroform, acetic acid, sulfuric acid & - \\
Phenols & Iron (II) chloride & +
\end{tabular}

+: Present, -: Absent

re-growth after application of the $R$. vulgaris methanol extracts need to be conducted. The modern use of antibacterial agents with harmful side effects has resulted in a significant need for the development of alternatives which are safe and cost-effective [2]. The use of medicinal plants in drug production is preferable as they are biodegradable, affordable to produce and readily available [37].

\section{Conclusions}

The antimicrobial potential demonstrated by $R$. vulgaris extracts supports its traditional use as a toothbrush. However, the cytotoxicity demonstrated by the extracts as well as the mild irritation needs further study before $R$. vulgaris can be recommended for the development of effective and safe mouthwashes.

\section{Abbreviations \\ C. albicans: Candida albicans; $\mathrm{CO}_{2}$ : Carbon (IV) oxide; CMR: Centre for microbiology research; DMSO: Dimethyl sulfoxide; FBS: Fetal bovine serum; $\mathrm{FeCl}_{2}$ : Iron (II) oxide; $\mathrm{FeCl}_{3}$ : Iron (III) oxide; $\mathrm{MBC}$ : Minimum bactericidal concentration; MEM: Minimum essential medium; MeOH: Methanol; DCM: Dichloromethane; MIC: Minimum Inhibitory concentration; OECD: Organisation for Economic co-operation and development; MIC/ MBC: Minimum inhibition concentration/ minimum bactericidal concentration; MRSA: Methicillin-resistant Staphylococcus aureus; MTT: 3-(4,5- Dimethylthiazol-2-YI)-2,5-diphenyltetrazolium bromide; R. vulgaris: Rhus vulgaris; S. aureus: Staphylococcus aureus; S. mutans: Streptococcus mutans}

\section{Acknowledgements \\ The authors give special thanks to the director of Kenya Medical Research Institute (KEMRI), the director of the Centre for Traditional Medicine and Drug Research (CTMDR), the director of the Centre for Microbiology Research (CMR) and all the staff members of both CTMDR and CMR. In addition, we would also like to thank the University of Eldoret and the Center of Excellence in Phytochemicals, Textiles and Renewable Energy (PTRE), Moi University, for their support during this study.}

\section{Authors' contributions}

AM - Study design, Literature search, data collection, data analysis, data interpretation, writing manuscript, LM - Research supervision, Study design, editing manuscript, LK - Research supervision, editing manuscript, JO Provision of reagents and materials used in the study, RK - Performing antimicrobial assays, TC - Performing phytochemical analysis, assisted with conducting literature search, JK - Study design, supervision of acute oral toxicity and acute dermal corrosion, PM - Research supervision, editing manuscript. All authors read and approved the final manuscript.

\section{Funding}

The funding for this study was availed by KEMRI Internal Research Grants (IRG) which was awarded to Ms. Joyce Ondicho- PI and Dr. Peter MwitariCo-PI during the financial year 2016/2017. The award number was IRG/172/6. KEMRI Internal Research Grants provided the funds for the facilitation of the collection of plant materials and the provision of all the consumables utilized during this study.

\section{Availability of data and materials}

All data generated or analysed during this study are included in this published article.

\section{Ethics approval and consent to participate}

Approval to carry out this work was obtained from the KEMRI Scientific and Ethics Review Unit (SERU) and Animal Care and Use Committee (ACUC). This study was assigned the number KEMRI/SERU/CTMDR/038/3379.

\section{Consent for publication}

Not applicable.

\section{Competing interests}

The authors declare that they have no competing interests.

\section{Author details}

${ }^{1}$ Department of Biological Sciences, University of Eldoret, P.O. Box 1125-30100, Eldoret, Kenya. ${ }^{2}$ Centre for Traditional Medicine and Drug Research, Kenya Medical Research Institute, P.O. Box 54840-00202, Nairobi, Kenya. ${ }^{3}$ Centre for Microbiology Research, Kenya Medical Research Institute, P.O. Box 54840-00202, Nairobi, Kenya.

Received: 31 March 2020 Accepted: 28 August 2020

Published online: 10 September 2020

\section{References}

1. Kassebaum NJ, Smith AG, Bernabé E, Fleming TD, Reynolds AE, Vos T, Murray CJ, Marcenes W. GBD 2015 Oral health collaborators. Global, regional, and national prevalence, incidence, and disability-adjusted life years for oral conditions for 195 countries, 1990-2015: a systematic analysis for the global burden of diseases, injuries, and risk factors. J Dent Res. 2017; 96(4):380-7. https://doi.org/10.1177/0022034517693566.

2. Palombo EA. Traditional medicinal plant extracts and natural products with activity against oral bacteria: potential application in the prevention and treatment of oral diseases. Evid Based Complement Alternat Med. 2011;1: 2011. https://doi.org/10.1093/ecam/nep067.

3. Abdollahzadeh $\mathrm{SH}$, Mashouf RY, Mortazavi H, Moghaddam MH, Roozbahani $\mathrm{N}$, Vahedi M. Antibacterial and antifungal activities of Punica granatum peel extracts against oral pathogens. J Dent (Tehran, Iran). 2011;8(1):1.

4. Shekar BR, Nagarajappa R, Suma S, Thakur R. Herbal extracts in oral health care-a review of the current scenario and its future needs. Pharmacogn Rev. 2015;9(18):87. https://doi.org/10.4103/0973-7847.162101.

5. Ferrazzano GF, Amato I, Ingenito A, Zarrelli A, Pinto G, Pollio A. Plant polyphenols and their anti-cariogenic properties: a review. Molecules. 2011; 16(2):1486-507. https://doi.org/10.3390/molecules16021486.

6. Rayne S, Mazza G. Biological activities of extracts from sumac (Rhus spp.): a review. Nat Precedings. 2007:1. https://doi.org/10.1038/npre.2007.631.1.

7. Njoroge GN, Bussmann RW, Gemmill B, Newton LE, Ngumi WW. Utilisation of weed species as sources of traditional medicines in Central Kenya. Lyonia. 2004 Jun 28:7(2):71-87.

8. Okullo JB, Omujal F, Bigirimana C, Isubikalu P, Malinga M, Bizuru E, Agea JG. Ethnomedicinal uses of selected indigenous fruit trees from the Lake Victoria Basin districts in Uganda. J Med Plants. 2014;2(1):78-88.

9. Odongo CO, Musisi NL, Waako P, Obua C. Chewing-stick practices using plants with anti-streptococcal activity in a Ugandan rural community. Front Pharmacol. 2011;2:13.

10. Ochanga $\mathrm{O}$, Chacha M. In vitro antibacterial activity of plants used as herbal tea in Tanzania. J Complement Altern Med Res 2016 23:1-0; doi:https://doi. org/10.9734/JOCAMR/2016/30263.

11. Ochanga $\mathrm{O}$, Kilonzo M. Antioxidant properties of aqueous and ethyl acetate extracts of some plants used as herbal tea in Tanzania. Oxidants Antioxid Med Sci. 2018;7(1):1-8. https://doi.org/10.5455/oams.20180207075358. 
12. Ochanga $\mathrm{O}$, Chacha M. Antifungal and cytotoxicity activity of plants used as herbal teas in Tanzania. Eur J Med Plants. 2016;15:1-8. https://doi.org/10. 9734/EJMP/2016/29475.

13. Odongo E, Mungai N, Mutai P, Karumi E, Mwangi J, Kimondo J, Omale J, Simiyu J. Antioxidant and anti-inflammatory activities of selected medicinal plants from western Kenya. 2017.

14. Salhi N, Mohammed Saghir SA, Terzi V, Brahmi I, Ghedairi N, Bissati S. Antifungal activity of aqueous extracts of some dominant Algerian medicinal plants. Biomed Res Int. 2017;1:2017. https://doi.org/10.1155/2017/7526291.

15. Chigayo K, Mojapelo PE, Mnyakeni-Moleele S, Misihairabgwi JM. Phytochemical and antioxidant properties of different solvent extracts of Kirkia wilmsii tubers. Asian Pac J Trop Biomed. 2016;6(12):1037-43. https:// doi.org/10.1016/j.apjtb.2016.10.004.

16. Nawaz H, Shad MA, Rehman N, Andaleeb H, Ullah N. Effect of solvent polarity on extraction yield and antioxidant properties of phytochemicals from bean (Phaseolus vulgaris) seeds. Br J Pharm Sci 2020;56; doi:10.1590/ s2175-58797902019000417129.

17. Truong DH, Nguyen DH, Ta NT, Bui AV, Do TH, Nguyen HC. Evaluation of the use of different solvents for phytochemical constituents, antioxidants, and in vitro anti-inflammatory activities of Severinia buxifolia. J Food Qual. 2019;1:2019. https://doi.org/10.1155/2019/8178294.

18. Fall AD, Sy AN, Dieng SI, Sarr A, Dieng M. Phytochemical screening and free radical scavenging activity of Hydroethanolic leaf extract of Senna sieberiana DC (Caesalpiniaceae) and its fractions. Eur J Med Plants. 2019;11:1-6.

19. Khattak KF. Effect of geographical distributions on the nutrient composition, phytochemical profile and antioxidant activity of Morus nigra. Pak J Pharm Sci. 2015;28(5):1671-78.

20. Sayyad M, Tiang N, Kumari Y, Goh BH, Jaiswal Y, Rosli R, Williams L, Shaikh MF. Acute toxicity profiling of the ethyl acetate fraction of Swietenia macrophylla seeds and in-vitro neuroprotection studies. Saudi Pharm J. 2017;25(2):196-205. https://doi.org/10.1016/j.jsps.2016.05.002.

21. Simon AO, Festus MT, Makokha AO. Preclinical anti-HSV-1 activity of aqueous and methanol extracts of Kenya grown pyrethrum (Chrysanthemum cinerariaefolium). J Med Plants Res. 2016;10(44):8117. https://doi.org/10.5897/JMPR2016.6078.

22. Thirumurugan $\mathrm{K}$, Shihabudeen MS, Hansi PD. Antimicrobial activity and phytochemical analysis of selected Indian folk medicinal plants. Steroids. 2010;1(7): 430-34.

23. Sánchez E, Morales CR, Castillo S, Leos-Rivas C, García-Becerra L, Martínez DM. Antibacterial and antibiofilm activity of methanolic plant extracts against nosocomial microorganisms. Evid Based Complement Altern Med. 2016;2016. https://doi.org/10.1155/2016/1572697.

24. Konaté K, Mavoungou JF, Lepengué AN, Aworet-Samseny RR, Hilou A, Souza A, Dicko MH, M'Batchi B. Antibacterial activity against $\beta$-lactamase producing methicillin and ampicillin-resistants Staphylococcus aureus: fractional inhibitory concentration index (FICl) determination. Ann Clin Microbiol Antimicrob. 2012:11(1):18.

25. Radol AO, Kiptoo M, Makokha AO, Tolo FM. Cytotoxicity and anti-herpes activity of selected medicinal plants cited for management of HIV conditions in Kakamega County-Kenya. J Pharm Res Int. 2016;22:1-3. https://doi.org/10.9734/BJPR/2016/29317.

26. Mengiste B, Dires K, Lulekal E, Arayaselassie M, Zenebe T, Feleke G, Makonnen E, Mekonnen A. Acute skin irritation, acute and sub-acute oral toxicity studies of Rosmarinus officinalis essential oils in mice and rabbit. Afr J Pharm Pharmacol. 2018;12(26):389-96. https://doi.org/10.5897/AJPP2018.4957.

27. Pinto ND, Machado DC, da Silva JM, Conegundes JL, Gualberto AC, Gameiro J, Chedier LM, Castañon MC, Scio E. Pereskia aculeata miller leaves present in vivo topical anti-inflammatory activity in models of acute and chronic dermatitis. J Ethnopharmacol. 2015;173:330-7. https://doi.org/10.1016/j.jep. 2015.07.032

28. Alhaddad H, Fadhil AA, Ismael SH. Estimation of LD50 and Acute Toxicity of Zygophyllum fabago in Mice. Am J Pharm Sci. 2015;3(4):94-7. https://doi.org/ 10.12691/ajps-3-4-2.

29. Gul R, Jan SU, Faridullah S, Sherani S, Jahan N. Preliminary phytochemical screening, quantitative analysis of alkaloids, and antioxidant activity of crude plant extracts from Ephedra intermedia indigenous to Balochistan. Sci World J. 2017;1:2017. https://doi.org/10.1155/2017/5873648.

30. Fayaz M, Bhat MH, Kumar A, Jain AK. Comparative studies on different solvents used for the extraction of phytochemicals from the plant parts of Arnebia benthamii.(wall ex. G. Don) Johnston. J Chem Pharm Res. 2017;9(1): $220-4$.
31. Anthoney ST, Ngule CM, Obey J. Phytochemical analysis of Vernonia adoensis leaves and roots used as a traditional medicinal plant in Kenya. Int J Pharm Biol Sci. 2013;3(3):2230-7605.

32. Roufegari Nejad A. The association between caries and periodontal diseases. 2012

33. Inaba H, Amano A. Roles of oral bacteria in cardiovascular diseases-from molecular mechanisms to clinical cases: implication of periodontal diseases in development of systemic diseases. J Pharmacol Sci. 2010;113(2):103-9. https://doi.org/10.1254/jphs.09R23FM.

34. Henley-Smith CJ, Botha FS, Lall N. The use of plants against oral pathogens. Formatex. 2013;30:1375-84.

35. Abuto JO, Muchugi A, Mburu D, Machocho AK, Karau GM. Variation in antimicrobial activity of Warburgia ugandensis extracts from different populations across the Kenyan Rift Valley. J Microbiol Res. 2016;6(3):55-64. https://doi.org/10.5923/j.microbiology.20160603.02

36. Merawie Y, Sahile S, Moges F, Husen A. Antimicrobial activity of crude and semi-purified fractions of Warburgia ugandensis against some pathogens. J Coastal Life Med. 2013;1(3):184-91.

37. Dar RA, Shahnawaz M, Qazi PH. General overview of medicinal plants: a review. J Phytopharmacology. 2017;6(6):349-51.

\section{Publisher's Note}

Springer Nature remains neutral with regard to jurisdictional claims in published maps and institutional affiliations.
Ready to submit your research? Choose BMC and benefit from:

- fast, convenient online submission

- thorough peer review by experienced researchers in your field

- rapid publication on acceptance

- support for research data, including large and complex data types

- gold Open Access which fosters wider collaboration and increased citations

- maximum visibility for your research: over $100 \mathrm{M}$ website views per year

At BMC, research is always in progress.

Learn more biomedcentral.com/submissions 